\title{
Axel Haunschild*
}

\section{Contingent Work: \\ The Problem of Disembeddedness and Economic Reembeddedness ${ }^{* *}$}

All economic action is embedded in social contexts (Granovetter 1985). However, contingent work practices make work relations more episodic, transient and marketlike. They produce dislocated and time-space spanning social contexts and, therefore, contribute to what Giddens (1990) has called the process of disembedding. The aim of the paper is to relate contingent work practices to a wider societal context by looking at how these disembedded practices become reembedded in local contexts of interaction. For situations in which means-end calculations are the dominant focus of social relations and in which social interactions are, for the most part, consciously reflected as resource exchange relations, the term economic reembedding is suggested. But illustrated by Bourdieu's notion of social capital - the paper also explores limits to an economization of social relations in general and of work practices in particular. In conclusion, some implications for firms' utilization, management, and reproduction of human resources are discussed that follow on from the embeddedness perspective on contingent work developed in the paper.

Key words: Contingent work, disembeddedness, economic reembedding, embeddedness, human, resource management, social capital

* Dr. Axel Haunschild, Universität Hamburg, Fachbereich Wirtschaftswissenschaften, IÖP, Von-Melle-Park 5, D - 20146 Hamburg, Tel.: ++49 40 42838-4101, Fax. ++49 40 42838-6358, E-Mail: haunsch@econ.uni-hamburg.de.

** A first draft of this paper was presented at the 18th EGOS Colloquium, 4-6 July, 2002 in Barcelona, Spain; sub theme 15: Temporary and Scattered Work Practices; convenors: Christina Garsten, Ann Westenholz, and John Purcell. I wish to thank the two anonymous reviewers and Thomas Crowe for their helpful comments. I would also like to thank Manfred Moldaschl for his support.

Article received: November 30, 2003

Revised version accepted after double blind review: April 11, 2004. 


\section{Introduction}

The theory of the firm increasingly devotes attention towards social relations as resources which have a crucial effect on organizational success (Dyer/Singh 1998; Nahapiet/Goshal 1998). Furthermore, referring to the resource-based view of the firm (Penrose 1959; Barney 1991) and its offspring, the knowledge-based view of the firm, workers are seen as human resources that can provide competitive advantages and that have to be linked to the organization by appropriate contractual arrangements (Matusik/Hill 1998, Lepak/Snell 1999, Burton-Jones 1999). These theoretical developments support the standpoint taken up by most social scientists, that economic action is embedded in social contexts (Granovetter 1985; Hollingsworth/Boyer 1997; Maurice/Sorge 2000; Moldaschl 2003). Whereas the views mentioned accentuate the (growing) importance of human knowledge, social ties and trust from an organizational perspective, recent sociological diagnoses of postmodern or late modern societies state processes of fragmentation (Sennett 1998; Bauman 1995) and disembedding (Giddens 1990). By disembedding, Giddens means „the 'lifting out' of social relations from local contexts of interaction and their restructuring across indefinite spans of time-space" (Giddens 1990: 21). An important precondition of disembedding is, according to Giddens, the emptying (separation) of time and space in combination with the separation of space from place as a physical setting of social activity.

New, contingent work arrangements play an important role in the societal production of these disembedding and dislocating processes and are results of these processes. The rationalization or colonization of our Lebenswelt was diagnosed many years ago by Max Weber (1972 [1922]) and, later, by Jürgen Habermas (1981; see also Smith/Kulynych 2002: 163), and Karl Polanyi (1944) has analyzed how in the course of the industrial revolution the commodification of labor has dissolved the social and cultural embeddedness of workers and their families. However, new developments such as flexible labor and flexible workplaces, as well as the rising power of organizations (Perrow 1991), seem to accelerate (or revive) these processes. Additionally, as most of the so-called atypical work arrangements lead to more market-related transactions and fuzzy boundaries between work and private spheres, economic calculations (means-end-rationality) might also become dominant for social relations vaguely related to the work sphere. Despite these processes of disembedding, synchronous interactions between human beings are still an important basis of our (working) lives. Giddens (1990: 79, 88) names the reappropriation of faceless commitments and disembedded social relations by 'facework' reembedding.

The aim of the paper is to relate contingent work practices to a wider societal context by looking at how these disembedded practices become reembedded in local contexts of interaction. The paper argues that analyzing contingent work as embedded, disembedded and reembedded social practice helps to understand how human resources are managed, utilized and reproduced at firm level.

In the next three sections, I will sketch Granovetter's notion of embeddedness of economic action and Giddens' concept of disembedding. I will also characterize contingent work arrangements and discuss to what extent contingent work practices are disembedded social practices. The second part of the paper explores whether today's 
work and social relations can be characterized by a growing 'economization', i.e. if work practices are nowadays reembedded in a mainly economic framework. There are different developments which support such a diagnosis: (1) intra-organizational relations where market mechanisms substitute for hierarchical mechanisms of coordination (e.g. profit centers or intra-organizational supplier-customer relations), (2) neo-Tayloristic work arrangements as found, for example, among call centers, where the dominant motive of working in exchange for money becomes obvious, and (3) market-mediated work relations, which substitute standard employment relations (e.g. fixed-term contracting and temporary work). In analyzing how reembedding of contingent work relations takes place, the paper focuses on the latter aspect. Contingent work practices change work identities and make social relations more episodic, transient, market-like, and (perhaps) more superficial. But conceptualizing more marketlike ways of contracting work as an economic reembedding of disembedded work practices, raises the question as to what extent economization is possible or to be expected. This question will be discussed by referring to the concept of social capital. Bourdieu (1983) stresses that social capital (as accumulated investment in relationships) requires continuous reproduction and has long-term effects which prohibit the possibility of short-term calculations. In Bourdieu's notion of social capital there is also a dimension of disguise concerning the transformation of one form of capital into another. Especially, the transformation from economic capital into social capital and the other way round, is normally not made explicit. Thus, when an economic motivation for investment in social capital becomes manifest, non-intended consequences of these actions have to be taken into account. Even if the way we interact becomes more reflective (Giddens 1990; Beck et al. 1994), it has to be assumed that there are limits when basing social relations on economic calculations or even market mechanisms.

Finally, the paper deduces from the embeddedness perspective on contingent work developed so far some implications for firms' management, utilization and reproduction of human resources. Rather than pursuing an economistic approach, economic reembedding stresses the inherently social dimension of economic action. In the case of work practices and work arrangements, economic reembedding draws attention to alterations in the way work relations are socially embedded and how these alterations affect the usage and reproduction of human and social resources.

\section{The Embeddedness of Economic Action}

Mark Granovetter, in his distinguished article 'Economic Action and Social Structure: The Problem of Embeddedness' (1985), criticizes the disregard of ongoing structures of social relations in economic theorizing. Economists, in his opinion, neglect the historical and structural embeddedness of relations (ibid.: 486). He illustrates his argument by a critique of Williamson's (1975) 'markets and hierarchies' research program. According to Granovetter, Williamson overestimates the efficacy of hierarchical power within the firm (oversocialized conception) and underestimates the role of concrete networks of personal relations on markets and across organizational boundaries (undersocialized conception). Granovetter remarks that a fruitful analysis of economic action requires paying , careful and systematic attention to the actual patterns of per- 
sonal relations by which economic transactions are carried out" (1985: 504). Although he develops this argument with regard to economic action, Granovetter emphasizes that his account holds true for all behavior.

Granovetter concedes, though, that he has ,had little to say about what broad historical or macrostructural circumstances have led systems to display the socialstructural characteristics they have" and that he, therefore, makes no claim for his analysis „to answer large-scale questions about the nature of modern society or the sources of economic and political change“ (1985: 505). Thus, Granovetter points out that economic action is embedded in social contexts, but the concept of embeddedness does not provide means to analyze changes in the way economic and personal relations are interlinked in society (see also Barber 1995). As the next section will show, this is, however, necessary when discussing the consequences of new, more flexible and contingent work relations.

\section{Contingent Work}

Full-time, regular employment, which was and partly still is prevalent and ideologically significant (Garsten 1999), has developed hand in hand with Fordistic forms of production and contributed to arrest high labor mobility in times when capital and labor were highly interdependent (Bauman 2001; other arguments concerning the advantages of employment contracts are, for example, given by Coase 1937; Simon 1951; Marsden 1999). In the last decade or two, new or 'atypical' forms of work such as temporary work, self-employment and teleworking have become more prevalent.

The term contingent work, which commonly covers temporary service workers, involuntary part-time workers and the self-employed (Polivka/Nardone 1989; Barker/Christensen 1998), accentuates the uncertainty, insecurity and arbitrariness of these work relations from the employees' viewpoint. Contingent workers do „not have an explicit or implicit contract for long-term employment“ and/or their „minimum hours worked can vary in a nonsystematic manner" (Polivka/Nardone 1989: 11). Contingent work together with work forms, that transgress formerly given timespace boundaries (e.g. teleworking), lead to heterogeneous patterns of presence at and absence from the workplace and to a growing non-permanence and transitoriness of work relations. Thus, long and intense work relations become more unlikely. As Garsten stresses, this „mobile and temporary character of assignments leads to the development of transient and episodic imagined communities of the workplace“" (1999: 601), with employees investing not much of their emotions in peers or places of work. The positional structure of an organization, hitherto a symbol of stable and reliable work relations and work behavior, increasingly calls for a time and a spatial dimension: When, until when and where can I find a certain job holder?

The effects of these contingencies on employees' biographies, life narratives and identities, as well as on communities and the society as a whole, have been extensively debated (Sennett 1998; Bauman 1995, 2001; Giddens 1990, 1991; Beck 1992; cf. also Brocklehurst 2001, who analyzes the recreation of work identities among new technology homeworkers). Putting aside all differences between these authors, they all agree that the stability of early modernity gives way to a fundamental insecurity. According to Bauman (2001: 24-25), today's working life is saturated with uncertainty, 
and the present-day uncertainty is an individualizing force, as it restricts the chance for loyalty and mutual commitment. As work practices are an important if not determining point of reference in our lives, contingent work arrangements contribute to this overall insecurity and lack of continuity and stability. But on the other hand, through 'short-term' mentality (Bauman 2001: 23), as well as through lack of a firm hold in the present, which makes claims on the future unlikely (Bauman 2001: 36, referring to Bourdieu 1997), temporariness of partnerships becomes a self-fulfilling prophecy. As Sennett has put it, under the conditions we live, „fleeting forms of association are more useful to people than long-term connections" (1998: 24). Thus, temporary and scattered work practices are self-enforcing.

\section{The Disembeddedness and Reembeddedness of Social Action}

Contingent work and its consequences can be interpreted as an element of general tendencies in the late modern age, especially of processes which were characterized as 'the emptying of time and space' and 'disembedding' (Giddens 1990, 1991). The separation of time and space in combination with the separation of space from place as a physical setting of social activity, is a precondition for disembedding and rationalized organization. By disembedding Giddens means „the 'lifting out' of social relations from local contexts of interaction and their restructuring across indefinite spans of time-space“ (Giddens 1990: 21). The mechanisms of disembedding - the creation of symbolic tokens, such as money, and the establishment of expert systems - enable relations between 'absent' others, i.e. these mechanisms connect presence and absence. This time-space distanciation is enhanced by information technologies that allow transcending of the limitations of the individual's presence by the 'stretching' of social relations across time and space (Giddens 1984). As Giddens (1990: 64, 79) points out, globalization, by linking local practices with globalized social relations, refers essentially to this stretching process.

But all this does not mean that facework commitments (local practices of interaction) become less important or that abstract systems replace personal relations. Rather, Giddens stresses that we live in a 'peopled world' and that disembedding mechanisms themselves provide new opportunities for the reinsertion of lifted out social relations (1990: 141-143). He therefore introduces the concept of reembedding as a counterpart or complement to disembedding mechanisms. By reembedding, Giddens means ,the reappropriation or recasting of disembedded social relations so as to pin them down (however partially or transitorily) to local conditions of time and place“" (Giddens 1990: 79). Processes of reembedding, thus, seem to fit into Granovetter's argument that individuals desire ,to derive pleasure from the social interaction that accompanies their daily work“ (1985: 498). „The widespread preference for transacting with individuals of known reputation“ (Granovetter 1985: 490) obviously supports Giddens' emphasis on the importance of facework commitment. But bringing these perspectives of embeddedness, disembeddedness and reembeddedness together raises some open questions and reveals some theoretical shortcomings of the analyses employed so far.

As human beings are social beings, all (economic) action is embedded in social relations. But the concrete way in which economic action is embedded in social relations changes over time (see the above accounts of high, late or postmodernity) and is 
largely influenced by cognitive, political and cultural aspects (Zukin/DiMaggio 1990; DiMaggio 1990). Evidence for cultural influence (we could call this the 'embeddedness of embeddedness') is, among others, provided by Hofstede (1994: 63-67) whose individualism index refers to the influence of personal and kinship ties on the workplace and economic transactions; and - with a contrasting methodological and epistemological approach to Hofstede - by the cross-national comparisons within the framework of societal analysis developed and conducted by Maurice and others (Maurice/Sorge 2000; Korsnes 2000; see also the overview by Dacin et al. 1999, of studies concerning the embeddedness of organizations).

For the analysis of new forms of work practices, we therefore have to go beyond the statement that social relations matter (Granovetter) and that disembedding mechanisms go hand in hand with reembedding (Giddens). Rather, we have to regard more intensively the quality of contemporary reembedding processes, which is how the embeddedness of work practices changes. As Bauman notes, reembedding is not at all without problems today, it rather is precarious („Le précarité est aujourd'hui partout", in Bourdieu's words, 1997):

'Disembeddedness' is now an experience which is likely to be repeated an unknown number of times in the course of an individual life since few if any 'beds' for 're-embedding' look solid enough to augur the stability of long occupation... There is no prospect of a ' $\mathrm{fi}$ nal re-embeddedness' at the end of the road; being on the road has become the permanent way of life of the (now chronically) disembedded individuals. (Bauman 2001: 146)

Both Giddens (1990: 108) and Bauman (2001: 37, 40) see a devaluation, a destroyed primacy of place. Sennett's analysis indicates that the characteristics of temporary and contingent work practices, which continuously require new work partners, reduce worker's opportunities ,,to derive pleasure from the social interaction that accompanies their daily work“ (Granovetter 1985: 498). Putting Granovetter's and Sennett's accounts together, contingent work practices are precarious in the sense that they provide less opportunities for workers to achieve their preferences concerning the embeddedness of their daily (work) life. Thus, the question „, to what extent economic activity is mediated by ... networks of personal relations" (Granovetter 1990: 96), i.e. the 'problem of embeddedness', becomes a problem not only for social scientists but for (almost) all social actors in late modernity.

\section{Economic Reembedding}

As mentioned, Giddens (1990: 21-29) identifies money (as one important kind of symbolic token) and expert systems as disembedding mechanisms. But while discussing access points of abstract systems as a meeting ground of facework and faceless commitments (1990: 83-88), Giddens pays little attention to the role of money in processes of reembedding. This section deals with the question as to what extent social interaction can be characterized by a growing economization, and it introduces the term economic reembedding to characterize processes of reembedding in which social interactions are, for the most part, consciously reflected as resource exchange relations.

Instrumental rationality, i.e. selecting the best means to given ends, is at the core of what we could call 'economic action'. The term 'economic man' or 'homo oeconomicus', on the one hand, refers to a methodological approach aiming at explain- 
ing individual behavior and social phenomena. On the other hand, it refers to a specific model of human beings as (bounded) rationality-driven, calculating, utility-maximizing and socially neutral individuals. In this sense, a growing rationalization as described by Weber (1972 [1922]; critically Giddens 1990; Bauman 2001: 145-146, 151) - instrumental rationality becoming the dominant focus of social (inter)action - could be named economization. Critical accounts of 'the economy' (see, for example, Klein 2000; Chomsky 1998; Forrester 1996; Saul 1995) emphasize the growing economic rationality and the growing power of money and organizations in our (global) society.

Another, though not completely different, notion of economization is that of an increase in market transactions and market oriented behavior. It has been argued, that in western cultures markets occupy a central place in our lives and that, not only our position as consumers, producer or employees, but also our leisure time, is increasingly regarded against the background of market transactions and influences (Garsten 2001). Along with these developments, market or market-like transactions become more prevalent in organizations (Moldaschl/Sauer 2000; see Eccles/White 1988 for a discussion of transfer prices; see also Coleman's concept of positional viability, 1990: 448). It is, however, problematic to equate economy with market transactions. On the one hand, pure market transactions are only a theoretical borderline case (which is also Granovetter's argument), on the other hand, this would imply that transactions in hierarchies (bureaucracies) and other hybrid institutional arrangements, such as network organizations, are not economic. This is obviously not what (non-neo-classical) economics intends. Homo mercatis (who orients large parts of his behavior towards market transactions) is, therefore, - as Garsten (2001) notes - a special version of homo oeconomicus. To equate economization with a growing reflexivity ${ }^{1}$ in our lives is problematic as well, because this would subsume all forms of (conscious) knowledge application under the notion of economic behavior. Nevertheless, reflexivity is an important catalyst for economization.

In the following, the term economization is used to describe the tendency of a growing reference to means-end-rationality and a growing reflection of social interactions as resource exchange relations. It is self-evident that money, as a symbolic token, plays a far-reaching role here. In a capitalist system, the accumulation of money (economic capital) becomes an end in itself: money serves as a measure for evaluating inputs (means, behavior), and money enables resource exchange with an infinite number of others (cf. Matiaske 1999). Economic reembeddedness then refers to situations in which disembedded social relations (which includes work relations) become reembedded in contexts in which facework is formed or influenced mainly by reflecting it as being a resource exchange relation.

The next section discusses to what extent new, contingent work practices and relations can be characterized as being economically reembedded.

1 Reflexivity as a characteristic of modernity refers to the fact ,,that social practices are constantly examined and reformed in the light of incoming information about those very practices, thus constitutively altering their character" (Giddens 1990: 38; see also other notions of reflexivity in Beck et al. 1994). 


\section{The Economic Reembeddedness of Contingent Work Practices Traditional Forms of Work}

Giddens characterizes the commodification of labor as a „particularly important point of linkage between capitalism and industrialism" (1990: 61). The development of abstract labor and the capitalistic labor contract have made selling one's labor for money a specific, historically new economic transaction. Although it can be said that labor is bought and sold on markets, these markets have become more and more regulated and institutionally embedded (Marsden 1986; Kallinikos 2002, who points to the heterogeneity of this process), and the transformation of labor from latent capacity into performance (Braverman 1974) takes place mainly in corporations or hierarchies. Although working in organizations always comprises an economic exchange, labor process debate has shown how indirect control (Edwards 1979) and the 'manufacturing consent' (Burawoy 1979) contribute towards disguising this economic core of industrial labor. Identification with and loyalty to an employer, as well as enduring and intense relationships to colleagues have - not for all, but for many - reduced the awareness of economic transactions in daily work practices significantly (see also Boltanski/Chiapello 2001).

Of course, organizational agents always conducted economic transactions for the organization, but the ideas of intrapreneuring (Pinchot 1986) and intra-organizational supplier-customer relations reinforce the return of workers' perception of themselves (or their capabilities, respectively) as a product to be maintained continuously marketable. Another development which makes labor as a commodity more visible is the phenomenon of 'neo-Tayloristic' workplaces, such as call centers (see, for example, Frenkel et al. 1998) or offices and work environment enforcing team Taylorism (Baldry et al. 1998). In both cases, internal market relations and neo-Taylorism, work relations are more economic in the sense that means-end calculations and resource exchange become the dominant focus of action.

\section{Flexible Forms of Work}

Contingent work relations such as temporary work and self-employment require a significant amount of flexibility from workers concerning their adaptation to changing work partners, the place of work and, sometimes, the tasks they perform. Furthermore, the relation between worker (contractor) and employer (client, customer) grows closer to market-based relations, with sales contracts as the basis of transactions.

For temporary employees, Garsten comes to the conclusion that they

... are being made up as subjects with a particular set of attitudes, skills, and scripts. They are taught to integrate market competitiveness into their daily actions, to make themselves marketable and employable. An important aspect of this involves adapting a flexible attitude to the client needs and to the staffing agency. This entails developing a portfolio of transferable skills as well as a transferable sense of self, that combines scripting and local knowledge to facilitate movement across workplaces. Not least, they learn to constitute themselves reflexively as flexible employees ... (2001: 14)

Especially for temps, Bauman's remark holds true that „[b]onds and partnerships are viewed ... as things to be consumed, not produced" (2001: 157). Since the purchaser can demand a replacement when 'the product' is not to his full satisfaction, it can be ex- 
pected that it is not perceived as the task of both partners to „make the relationship work" (ibid.).

Similar to Garsten's assessment of temporary work, Voß and Pongratz (1998) emphasize the necessity for self-employed workers ('Arbeitskraftunternehmer') of both continuous self-marketing and active production of one's own capacity for work. In contrast to (permanent) temporary workers, the self-employed are involved in ongoing (individualized) negotiation with their employer or customer. In sum, Voß and Pongratz diagnose (and predict) for the self-employed an enhanced self-control, the economization of work capabilities and performances, and a growing diffusion of business aspects into the 'private' sphere.

Both groups of workers, temporary and self-employed, have to internalize the rules of the market (Moldaschl 2002), which implies the danger of self-exploitation and self-subjugation (Voß/Pongratz 1998) and which does not imply reflecting the rules of the game (Bauman 2001: 9-10). Furthermore, both groups of workers have to control and monitor themselves by enhanced reflexivity (Garsten 1999, 2001). With regard to the coupling between organization and individual, the medium of money (at least partly) is substituted for hierarchical subordination or directives (medium of power) (Mayrhofer/Meyer 2001).

It can be concluded that social encounters in contingent work contexts increasingly take place (and are evaluated) against the background of - more or less explicit economic criteria. This justifies characterizing processes of reembedding in the work sphere as (increasingly) economic. It should be stressed, however, that it has not been the aim of the preceding sections to claim an economization of society. Rather, the intention was to discuss the extent in which economic reembedding is characteristic of contingent work practices. In the next section, limits to economic reembedding will be explored by referring to Bourdieu's notion of social capital.

\section{Social Capital: Limits to Economic Reembedding?}

The concept of social capital addresses social relations as resources in which investments can be made and which facilitate the achievement of certain ends (Coleman 1988; Bourdieu 1983, 1984). Social capital as understood by Coleman (and Bourdieu), „inheres in the structure of relations between actors and among actors“" (1988: S98).

Although there is a common understanding among most scholars who have developed and applied the concept of social capital concerning these features, there are also considerable differences (which cannot be discussed in detail in this paper; see, for example, Matiaske 1999; Lin 2001; Robison et al. 2002; Adler/Kwon 2002). One difference is the question: Who derives benefit from social capital - an individual actor (Bourdieu's notion), or a social network or collective (Coleman's notion), or both (Nahapiet/Goshal's notion, 1998)? Adler and Kwon (2002) have marked the first view as external and the second as internal. In the following, I will refer to Bourdieu's use of the term social capital for two reasons. First, Bourdieu integrates the concept into a general concept of capital, including economic and cultural capital (see also Robison et al. 2002). Second, the concept of capital is integrated into a wider social theory (theory of social practice) and is linked to other concepts such as field, habitus and class. This allows linking distributions and processes of accumulation of capital to societal struc- 
tures of power and their reproduction (see also Smith/Kulynych 2002; critically Baert 1998). In addition, and this is considerably relevant for the discussion of economic reembedding, the transformation of one form of capital into another becomes subject of (theoretical and empirical) analysis.

Bourdieu (1983) emphasizes that transformation of capital inevitably requires transformation efforts. He also remarks that, on the one hand, economic capital is at the root of all forms of capital, but that, on the other hand, the other forms of capital cannot entirely be transformed back into economic capital. Economization of social relations could now mean that investment in social relations becomes the result of intentional, calculated behavior with respect to future economic outcomes. This is what the term investment seems to imply anyway, but Bourdieu underlines that investments in social relations follow a logic of affective rather than intentional behavior or conscious calculus. Furthermore, these investments are long-term investments (favors, gifts, visits) which are most effective when their economic root or their economic intentions are disguised (not least to the investor). This holds also for transforming social capital (back) into economic capital (see, for example, Bourdieu et al. 1981; see also Matiaske 1999). A structure of mutual obligations does not mean that this capital can be activated deliberately, i.e. there is no guarantee and certainty concerning the ease and effectiveness of using this form of capital (for examples see Bourdieu 1984, 1990). Granovetter (without reference to Bourdieu) comes to a similar conclusion:

The example of investment in contacts also points up to the extent to which noneconomic motives are mixed with economic ones. One's interaction with others is generally not confined to 'economic investment activity': As with other aspects of economic life, striving for sociability, approval, status, and power also enter in. Indeed, a perception by others that one's interest in them is mainly a matter of 'investment' will make this investment less likely to pay off; we are all on the lookout for those who only want to use us. (Granovetter 1992: 257)

Further research is, however, needed concerning the question whether individuals' willingness to accept explicit, transparent investment activities in social relations increases (see the next section for examples of trust relationships in dynamic labor markets).

In sum, the concept of social capital, as developed and applied by Bourdieu, illustrates the connection between economic and social capital and helps to show limits to transforming one form of capital into another. Even though some criticize using economic language for analyzing social relations (Smith/Kulynych 2002), it can be argued that such a concept reveals the limits to building up and using social relations for economic purposes. ${ }^{2}$ Bourdieu himself justifies his heavy use of economic metaphors (Baert 1998: 31; for another justification see Robison et al. 2002) by pointing to his intention of developing a general theory of economic practice which explains both in-

2 It is certainly no surprise that a concept such as social capital becomes widely used in a time in which the benefits collectives, e.g. individualized societies (Bauman 2001: 9, 24) or organizations (Nahapiet/Goshal 1998) can derive from social relations, become more uncertain or precarious (internal view) and in which social networks become crucial for individual success (external view). In this sense, the frequent use of such a concept itself might indicate an increasing economization. 
tentional and non-intentional strategies directed to all valuable goods or resources which are at stake in societal 'fields'.

\section{Some Implications for the Management of Human Resources}

In times of contingent work practices based on other, rather than regular, employment contracts, it is more likely that personal relations between (frequently changing) work partners are consciously reflected mainly as resource exchange relations. At present, however, no empirical evidence supports the hypothesis that contingent work practices generally reduce the intensity of social relations and the extent of (communities', firms' or individuals') social capital. Rather, studies of organizational fields where contingent work practices are already (or have always been) widespread such as the film industry (Jones 1996), theatre (Haunschild 2003), or Silicon Valley (Saxenian 1996), contradict such a hypothesis. These ('boundaryless career') industries have one thing in common, namely that social networks embedded in occupational communities play an important role for staying in business and for career paths (for a general discussion see Raider/Burt 1996; Arthur et al. 1999). Resources available through social ties provide decisive support for developing and, especially, offering and selling one's labor. The higher the intransparency on the relevant market for labor, the more important becomes network building and other forms of signaling market value (Becker/Haunschild 2003). It can be assumed (but should be more intensely studied at empirical level), that in many, if not most, cases temporary contracts are accompanied by long-term trust relations between clients, customers and temporary employment agencies. Garsten (2001) provides evidence for the latter by underlining the importance for 'temps' of being predictable and reliable despite (or because of) the temporariness of their work arrangements.

These examples of the (dis)embeddedness of contingent work relations as well as the limits to an economization of work relations discussed in the preceding section suggest the following implications for (studying) human resource management:

1. Contingent work requires workers who accept such forms of relations. Human beings have a culturally embedded understanding of how far their work relations can be economized, i.e. to what extent others can make use of them as resources.

2. As labor markets and work arrangements are a central part of society, employment policies contribute to the societal reproduction (creation) of human resources. Managing human resources, therefore, changes what is to be managed, i.e. the way resources can be used is changed by their usage.

3. From the first two points, it follows that there is no absolute or specific level of trust, intimacy, familiarity or nearness required in work relations. Rather, the discussion of economic reembedding has illustrated societal changes in this respect.

4. Whether making employment relations more contingent is of economic value depends very much on the characteristics of processes of embedding, disembedding and reembedding. The examples of boundaryless career industries reveal that there is no clear negative correlation between the numerical flexibility of an employer and his capability to benefit from social relations. But the examples also show that other forms of social relations take the place of stable social relations 
in internal labor markets. The 'quality' of the social relations and ties established

by contingent workers require further empirical elaboration, however.

All the points made show that the manner of how firms manage, utilize and reproduce human resources is deeply embedded in the firms' societal and cultural environment. It was not the aim of this section to address management issues by proposing how to improve human resource management economically. Rather than seeing contingent work mainly as a management problem, contingent work has been regarded from a societal perspective. This perspective goes beyond firm-based theories of human resource management and provides a wider understanding of the way (human) resources are constituted and used.

\section{Concluding Remarks}

The rise of contingent work relations contributes to processes of disembedding, and work practices are increasingly disembedded. This is because they become stretched across time and space and because their local context becomes more influenced by global phenomena. The paper has argued that reembedding of these disembedded, temporary and scattered, work practices, i.e. processes of sustaining or transforming faceless commitments by facework (Giddens 1990: 79), takes place under changing basic conditions. The examples of temporary work and self-employment have shown that perceiving and continuously producing oneself as an employable bearer of skills or a marketable product becomes a prime characteristic of work practices. The more the boundaries between work and non-work spheres become blurred, the more one is inclined to state an economization of day-to-day (work) life. The term economic reembedding was introduced to refer to such a process. ${ }^{3}$ By referring to Giddens' and Bauman's diagnoses of contemporary life (in western industrialized societies), this article has attempted to enrich Granovetter's generalizing emphasis on the embeddedness of economic action. Granovetter's assessment of what individuals expect from work or economic relations, namely embeddedness in social ties, was confronted with how contingent work relations are economically reembedded. With reference to Bourdieu's concept of social capital the paper has, though, demonstrated that an economization of social relations has its limits. These limits are due to the fact that processes of transforming one form of capital into another largely take place in 'obscurity' and conceal their underlying intentions. Social capital requires investment, but this (intended or non-intended) investment is, according to Bourdieu, more effective when made in disguise. Why this is has not been discussed in this paper. Here - as DiMaggio (1990) has suggested - a deeper analysis of the cultural embeddedness of embeddedness (in Granovetter's sense) is necessary.

3 Although there is no doubt that work practices change in the mentioned direction, an economization of the society as a whole has to be questioned. One argument of relevance here is that almost all societal, functionally differentiated subsystems besides the economic system such as politics, law, medicine, education and science (Luhmann 1995), have an increasing influence on our everyday behavior. Thus, economic calculations do not automatically imply that economization is the dominant tendency in society. Rather, an intensified reflexivity (in the sense of Giddens, 1990, 1991) seems to be an appropriate characterization of social practice today. 
This paper has linked conceptual problems related to processes of disembedding and reembedding to the empirical phenomenon of contingent work practices, to sociological diagnoses of late modernity, and to the concept of social capital. In doing so, the paper has contributed to a trans-disciplinary, socio-economic approach to studying work arrangements and human resource policies. Such an approach goes beyond a firm-centered, resource-based view of management and enriches a relationship-based view. The increase of individualized and market-based employment as well as blurred organizational boundaries particularly call for approaches that consider the social embeddedness of markets and market-based relations.

\section{References}

Adler, P.S./Kwon, S.-W. (2002): Social capital: Prospects for a new concept. In: Academy of Management Review, 27: 17-40.

Arthur, M./Inkson, K./Pringle, J. (1999): The new careers. Individual action and economic change. London: Sage.

Baert, P. (1998): Social theory in the twentieth century. Cambridge: Polity Press.

Baldry, C./Bain, P./Taylor, P. (1998): 'Bright satanic offices': Intensification, control and team Taylorism. In: Thompson, P./Warhurst, C. (eds.): Workplaces of the future. Houndmills: Macmillan Press: 163-183.

Barber, B. (1995): All economies are „embedded“: The career of a concept, and beyond. In: Social Research, 62: 387-413.

Barker, K./Christensen, K. (eds.) (1998): Contingent work: American employment relations in transition. Ithaca and London: Cornell University Press.

Barney, J. (1991): Firm resources and sustained competitive advantage. In: Journal of Management, 17: 99-119.

Bauman, Z. (1995): Life in fragments. Essays in postmodern morality. Oxford: Blackwell.

Bauman, Z. (2001): The individualized society. Cambridge: Polity Press.

Beck, U. (1992): Risk society: Towards a new modernity. London: Sage (in German: 'Risikogesellschaft. Auf dem Weg in eine andere Moderne'. Frankfurt a.M.: Suhrkamp, 1986).

Beck, U./Giddens, A./Lash, S. (eds.) (1994): Reflexive modernization. Stanford, Cal.: Stanford University Press.

Becker, K.H./Haunschild, A. (2003): The impact of boundaryless careers on organizational decisionmaking: An analysis from the perspective of Luhmann's theory of social systems. In: The International Journal of Human Resource Management, 14: 713-727.

Boltanski, L./Chiapello, E. (2001): Die Rolle der Kritik in der Dynamik des Kapitalismus und der normative Wandel. In: Berliner Journal für Soziologie, 11: 459-477.

Bourdieu, P. et al. (1981): Titel und Stelle: über die Reproduktion sozialer Macht. Frankfurt a.M.: Europ. Verl.-Anst.

Bourdieu, P. (1983): Ökonomisches Kapital, kulturelles Kapital, soziales Kapital. In: Kreckel, R. (ed.): Soziale Ungleichheiten. Goettingen: Soziale Welt, Sonderband 2: 183-198.

Bourdieu, P. (1984): Distinction: A social critique of the judgement of taste. London: Routledge and Kegan Paul (originally in French 1979).

Bourdieu, P. (1990): The logic of practice. Cambridge: Polity Press (originally in French 1980).

Bourdieu, P. (1997): Le précarité est aujourd'hui partout. In: 'Contre feux'. Paris: Liber-Raison d'Agir.

Braverman, H. (1974): Labor and monopoly capital. The degradation of work in the twentieth century. New York: Monthly Review Press.

Brocklehurst, M. (2001): Power, identity and new technology homework: Implications for 'new forms' of organizing. In: Organization Studies, 22: 445-466.

Burawoy, M. (1979): Manufacturing consent: Changes in the labor process under monopoly capitalism. Chicago: University of Chicago Press.

Burton-Jones, A. (1999): Knowledge capitalism. Business, work, and learning in the New Economy, Oxford: Oxford University Press.

Chomsky, N. (1998): Profit over people: Neoliberalism and global order. New York: Seven Stories Press. 
Coase, R.H. (1937): The nature of the firm. In: Economica, 4: 386-405 (reprinted in: Stigler, G.J./Boulding, K.E. (eds.) (1952): Readings in price theory. Homewood, Ill.: 331-351).

Coleman, J.S. (1988): Social capital in the creation of human capital. In: American Journal of Sociology, 94, Supplement: S95-S120.

Coleman, J.S. (1990): Foundations of social theory. Cambridge, Mass.: Belknap Press.

Dacin, M.T./Ventresca, M.J./Beal, B.D. (1999): The embeddedness of organizations: Dialogue and directions. In: Journal of Management, 25: 317-356.

DiMaggio, P. (1990): Cultural aspects of economic action and organization. In: Friedland, R./Robertson, A.F. (eds.): Rethinking economy and society. New York: Aldine: 113-136.

Dyer, J.H./Singh, H. (1998): The relational view: Cooperative strategy and sources of interorganizational competitive advantage. In: Academy of Management Review, 23: 660-679.

Eccles, R.G./White, H.C. (1988): Price authority in inter-profit center transactions. In: American Journal of Sociology, 94, Supplement: S17-S51.

Edwards, P.K. (1979): Contested terrain: The transformation of the workplace in the twentieth century. London: Heinemann.

Forrester, V. (1996): L’horreur économique. Paris: Librairie Arthème Fayard.

Frenkel, S.J./Tam, M./Korcynski, M./Shire, K. (1998): Beyond bureaucracy? Work organization in call centres. In: The International Journal of Human Resource Management, 9: 957-979.

Garsten, Chr. (1999): Betwixt and between: Temporary employees as liminal subjects in flexible organizations. In: Organization Studies, 20: 601-617.

Garsten, Chr. (2001): Flex fads: new economy, new employees. Paper presented at the 17th EGOS Colloquium, Lyon, France.

Giddens, A. (1984): The constitution of society. Outline of the theory of structuration. Cambridge: Polity Press.

Giddens, A. (1990): The consequences of modernity. Cambridge: Polity Press.

Giddens, A. (1991): Modernity and self-identity. Self and society in the late modern age. Cambridge: Polity Press.

Granovetter, M. (1985): Economic action and social structure: The problem of embeddedness. In: American Journal of Sociology, 91: 481-510.

Granovetter, M. (1990): The old and the new economic sociology: A history and an agenda. In: Friedland, R./Robertson, A.F. (eds.): Rethinking economy and society. New York: Aldine: 89-112.

Granovetter, M. (1992): The sociological and economic approaches to labor market analysis: A social structural view. In: Granovetter, M./Swedberg, R. (eds.): The sociology of economic life. Boulder, Col.: Westview Press: 233-263 (originally published in: Farkas, G./England, P. (eds.) (1988): Industries, firms, and jobs: Sociological and economic approaches. New York: Plenum Press).

Habermas, J. (1981): Theorie des kommunikativen Handelns. Bände 1 und 2. Frankfurt: Suhrkamp (paperback edition 1995).

Haunschild, A. (2003): Managing employment relationships in flexible labour markets: The case of German repertory theatres. In: Human Relations, 56: 899-929.

Hofstede, G. (1994): Cultures and organizations. Software of the mind. Intercultural cooperation and its importance for survival. London: HarperCollinsBusiness.

Hollingsworth, J.R./Boyer, R. (eds.) (1997): Contemporary capitalism. The embeddedness of institutions. Cambridge: Cambridge University Press.

Jones, C. (1996): Careers in project networks: the case of the film industry. In: Arthur, M.B./Rousseau, D.M. (eds.): The boundaryless career. A new employment principle for a new organizational era. New York and Oxford: Oxford University Press: 58-75.

Kallinikos, J. (2002): The institutional embeddedness of labour contracts: Remarks on the transformation of work. Paper presented at the $18^{\text {th }}$ EGOS Colloquium, Barcelona, Spain.

Klein, N. (2000): No logo: no space, no choice, no jobs. 10th print. London: Flamingo.

Korsnes, O. (2000): Towards a relational approach to the study of variety in the situated creativity of economic actors. In: Maurice, M./Sorge, A. (eds.): Embedding organizations. Societal analysis of actors, organizations and socio-economic context. Amsterdam and Philadelphia: John Benjamins: 7187.

Lepak, D.P./Snell, S.A. (1999): The human resource architecture: Toward a theory of human capital allocation and development. In: Academy of Management Review, 24: 31-48.

Lin, N. 2001: Social capital: A theory of social structure and action, Cambridge: Cambridge University Press. 
Lindon, J.R./Schmid, A.A./Siles, M.E. (2002): Is social capital really capital? In: Review of Social Economy, LX: 1-21.

Luhmann, N. (1995): Social systems. Stanford. Stanford University Press (in German: Soziale Systeme. Frankfurt a.M.: Suhrkamp, 1984).

Marsden, D. (1986): The end of economic man? Custom and competition in labor markets. New York: St. Martin's Press.

Marsden, D. (1999): A theory of employment systems. Micro-foundations of societal diversity. Oxford: Oxford University Press.

Matiaske, W. (1999): Soziales Kapital in Organisationen. Eine tauschtheoretische Studie. München und Mering: Hampp.

Matusik, S.F./Hill, Ch.W.L. (1998): The utilization of contingent work, knowledge creation, and competitive advantage. In: Academy of Management Review, 23: 680-697.

Maurice, M./Sorge, A. (eds.) (2000): Embedding organizations. Societal analysis of actors, organizations and socio-economic context. Amsterdam and Philadelphia: Jon Benjamins.

Mayrhofer, W./Meyer, M. (2001): To belong or not to belong - is that the question? New forms of coupling between organizations and the individuals and their consequences for careers. Paper presented at the 17th EGOS Colloquium, Lyon, France.

Moldaschl, M. (2003): Nachhaltigkeit von Arbeit und Rationalisierung. Eine integrative ressourcentheoretische Perspektive. Paper presented at the Conference on Sustainability of Work and Rationalization in Chemnitz, Germany, January 2003.

Moldaschl, M. (2002): Ökonomien des Selbst: Subjektivität in der Unternehmergesellschaft. In: Klages, J./Timpf, S. (Eds.): Facetten der Cyberwelt: Subjektivität, Eliten, Netzwerke, Arbeit, Ökonomie. Hamburg: VSA: 29-62.

Moldaschl, M./Sauer, D. (2000): Internalisierung des Marktes - Zur neuen Dialektik von Kooperation und Herrschaft. In: Minssen, H. (ed.): Begrenzte Entgrenzungen - Wandlungen von Organisation und Arbeit. Berlin: Edition Sigma: 205-224.

Nahapiet, J./Goshal, S. (1998): Social capital, intellectual capital, and the organizational advantage. In: Academy of Management Review, 23: 242-266.

Penrose, E.G. (1959): The theory of the growth of the firm, New York: Wiley.

Perrow, C. (1991): A society of organizations. In: Theory and Society, 20: 725-762.

Pinchot, G. (1986): Intrapreneuring: Why you don't have to leave the corporation to become an entrepreneur. New York et al.: Harper \& Row.

Polanyi, K. (1944): The Great Transformation. New York: Holt, Rinehart.

Polivka, A.E./Nardone, T. (1989): On the definition of 'contingent work'. In: Monthly Labor Review, December: 9-16.

Putnam, R.D. (2000). Bowling alone: The collapse and revival of American community. New York: Touchstone.

Raider, H.J./Burt, R.S. (1996): Boundaryless career and social capital. In: Arthur, M.B./Rousseau, D.M. (eds.): The boundaryless career. A new employment principle for a new organizational era. New York and Oxford: Oxford University Press: 187-200.

Saul, J.R. (1995): The unconscious civilization. Concord, Ontario: House of Anansi Press.

Saxenian, A.L. (1996): Beyond boundaries: Open labor markets and learning in Silicon Valley. In: Arthur, M.B./Rousseau, D.M. (eds.): The boundaryless career. A new employment principle for a new organizational era. New York and Oxford: Oxford University Press: 23-39.

Sennett, R. (1998): Corrosion of character: The personal consequences of work in the new capitalism. New York: W.W. Norton.

Simon, H.A. (1951): A formal theory of the employment relationship. In: Econometrica, 19: 293-305.

Smith, St.S./Kulynych, J. (2002): It may be social, but why is it capital? The social construction of social capital and the politics of language. In: Politics \& Society, 30: 149-186.

Voß, G.G./Pongratz, H.J. (1998): Der Arbeitskraftunternehmer. Eine neue Grundform der Ware Arbeitskraft? In: Kölner Zeitschrift für Soziologie und Sozialpsychologie, 50: 131-158.

Weber, M. (1972): Wirtschaft und Gesellschaft. $5^{\text {th }}$. edition. Tübingen:Mohr [first edition 1922].

Williamson, O.E. (1975): Markets and hierarchies. New York: Free Press.

Zukin, S./DiMaggio, P. (1990): Introduction. In: Zukin, S./DiMaggio, P. (eds.): Structures of capital. The social organization of the economy. Cambridge: Cambridge University Press: 1-36. 